\title{
Chapter 7 \\ Managing House Price Booms: Evolution of IMF Surveillance and Policy Advice
}

\author{
Hites Ahir and Prakash Loungani
}

\section{Introduction}

In April 2008, the IMF's flagship publication World Economic Outlook provided estimates of overvaluation in house prices for a group of advanced economies. Though house prices had fallen in the United States in the preceding years, they had continued to rise in many other countries. The IMF's analysis suggested that, with only a few exceptions, house prices were overvalued by between $10 \%$ and $30 \%$, as shown by the bars in Fig. 7.1. The dots show the decline in house prices that occurred over the subsequent 4 years. In many countries where the IMF had assessed house prices to be overvalued, house prices did indeed fall quite significantly-these cases include Denmark, Ireland, the Netherlands and the United Kingdom.

Fast forward to the present: The IMF's Global House Price Index - a simple average of real house prices for 57 countries-is now back to its level before the global financial crisis (GFC). The index has been inching up since 2012, making the duration of the run-up comparable to one in 2001-06 that ended in house price collapses in many countries. Is it time to worry again about overvaluation?

This chapter describes the evolution of IMF monitoring- "surveillance" in the IMF's jargon-of housing markets from 2008 to the present. Section 2 describes

The views expressed are those of the authors and should not be attributed to the IMF or the Independent Evaluation Office (IEO). This chapter builds on work largely carried out when the second author was in the IMF's Research Department and should not be considered as an IEO evaluation of IMF activities.

\section{H. Ahir}

IMF Research Department, Washington, DC, USA

e-mail: hahir@imf.org

P. Loungani $(\bowtie)$

IMF Independent Evaluation Office, Washington, DC, USA

e-mail: ploungani@imf.org 


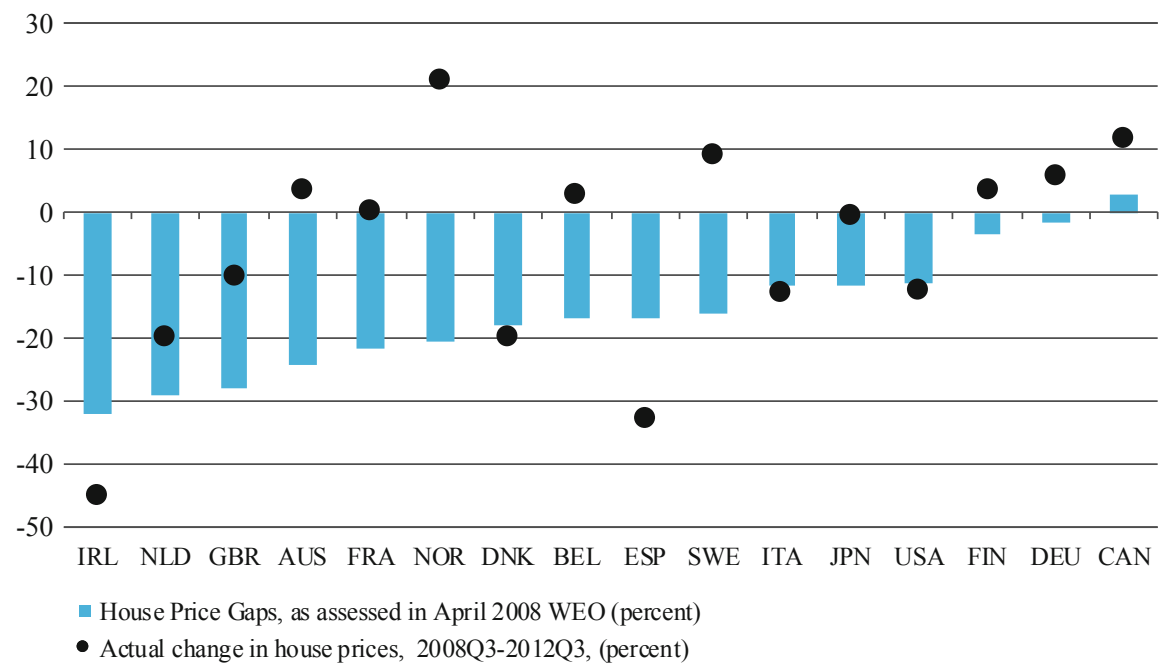

Sources: House price gaps: April 2008 World Economic Outlook (WEO). Change in house prices: IMF Global Housing Watch.

Labels: $A U S=$ Australia, $B E L=$ Belgium, $C A N=$ Canada, $D E U=$ Germany $D N K=$ Denmark,

$E S P=$ Spain, $F I N=$ Finland, $F R A=$ France, $G B R=$ Great Britain, $I R L=$ Ireland, $I T A=I$ taly, $J P N=$ Japan,$N L D=$ the Netherlands, NOR $=$ Norway, $S W E=$ Sweden, and USA $=$ United States

Fig. 7.1 Estimated overvaluation and subsequent house price changes

how the IMF has assessed overvaluation in housing markets and the advice it offered on the policy tools needed to manage house price booms. It lays out the IMF's 'corporate view' or 'house view' that macroprudential policies must be the first line of defense to deal with house price booms. Section 3 takes up the issue of whether the run-up in house prices over the past few years should be a source of worry. Section 4 describes how IMF surveillance has adapted as housing markets have become more 'glocalized' and developments at the sub-national level gain greater prominence. ${ }^{1}$ Section 5 has some concluding observations.

\section{The Changing Lines of Defense}

\subsection{Explaining Booms}

A common approach to explaining house price growth is to see to what extent it can be explained by fundamental drivers such as growth in real GDP and working age

\footnotetext{
${ }^{1}$ Encyclopedia Britannica defines glocalization as "a hybrid of globalization and localization: the importance of global [factors] occurring together with the increasing salience of local and regional [factors]".
} 
population. The underlying assumption is that these factors impart a demand-side momentum which, unless supply of housing is extremely elastic, translates into a short-term boost to housing prices.

Interest rates are another fundamental driver of house price growth. Often, some covariates, such as credit growth and equity price growth, are included to control for other difficult to measure factors that could be driving house price growth. An errorcorrection term, such as the lagged house price-to-income ratio, is included to allow reversion of house prices to historical norms.

Illustrative panel regressions of this kind are shown in Table 7.1, using quarterly data for a large number of countries since 1970. The coefficients of the independent variables all have the expected signs and are statistically significant. Real GDP growth, working age population growth and the short-term interest rate, along with an error- correction term (the lagged house price-to-income ratio), explain about $30 \%$ of the variation in house price growth. One can get similar explanatory power by replacing real GDP growth with growth in equity prices. Including all variables raises the explanatory power to about $40 \%$ and all variables stay statistically significant, except for equity prices.

The assessments of overvaluation shown in Fig. 7.1 were based on regressions of this kind, estimated country-by-country. Specifically, house price growth was modeled as a function of growth in disposable income per capita, short-term interest rates, long-term interest rates, credit growth, changes in equity prices and changes in working-age population. The "unexplained increase" in house prices could reflect omitted variables "but could also be interpreted as a measure of overvaluation and, therefore, used to identify which countries may be particularly prone to a correction in house prices" (IMF 2008).

Table 7.1 Drivers and covariates of real house price growth

\begin{tabular}{l|l|l|l}
\hline Independent variables & $(1)$ & $(2)$ & $(3)$ \\
\hline Real GDP (growth) & 0.3 & & 0.2 \\
\hline Working age population (growth) & 0.1 & 0.1 & 0.1 \\
\hline Short-term interest rate & -0.4 & -0.5 & -0.6 \\
\hline House price-to-income ratio (lagged) & -0.1 & -0.1 & -0.3 \\
\hline Credit (growth) & & 0.1 & 0.1 \\
\hline Equity prices (growth) & & 0.06 & 0.00 \\
\hline Fiscal balance (change) & & & -0.1 \\
\hline Constant & 1.1 & 2.3 & 1.5 \\
\hline R-square & 0.28 & 0.30 & 0.39 \\
\hline Number of observations & 3519 & 3148 & 2291 \\
\hline
\end{tabular}

Note: Numbers shown are coefficient estimates; all are significant at conventional levels (except the one shown in italics) 


\subsection{Managing Booms}

What policies, if any, should be used to address such overvaluations in house prices? In the April 2008 WEO, the IMF took a heterodox view. It noted that "central bank orthodoxy" was that monetary policymakers should not target a particular level of house (or other asset) prices and should respond to changes in house prices only if they affected output and inflation outcomes and expectations. However, the counterargument was that a pre-emptive monetary policy response "could diminish the risk that a bigger crash would occur later on, with serious consequences for the real economy and inflation."

The IMF balanced these considerations by suggesting that monetary policy should take a "risk management" approach. Under such an approach, "house prices would seem relevant for calculating the risks to the outlook for overall economic activity, particularly during periods of rapid change in house prices and when house prices seem to be moving out of line with historical norms," due to "speculative forces". It concluded, however, that monetary policy "should not bear the full weight of responding to asset price bubbles" and other policies could also have a critical role.

A year later, as the global financial crisis intensified, the IMF's policy message started to change. The IMF became a strong advocate of the use of unconventional monetary policies to close output gaps and raise inflation to target levels. It recognized that these policies could have the side-effect of triggering house price booms and it advocated that these risks should be managed largely by using macroprudential (and microprudential) policies. Such policies were the "first lines of defense in safeguarding financial stability," according to Vinals (2010), the IMF's Financial Counsellor.

As in the April 2008 WEO, the IMF did not advocate a clean break between monetary policy and considerations of financial stability. While monetary policy should not adopt financial stability as a goal, Viñals argued that "financial stability concerns should be integrated much more systematically into monetary policy decision making." The models and analysis needed to do this would take time, so "in the meantime," Viñals advocated "practical behavioral rules in order to ensure that financial stability considerations are sufficiently taken into account in the pursuit of price stability. I believe that monetary policy should lean-in a non-mechanistic way-against the buildup of financial imbalances during an upswing in the cycle (as exemplified in excessive credit growth or asset prices). More "leaning" in this stage will hopefully lead to the need for less "cleaning" in the downturn thus rendering monetary policy more symmetric over the business cycle." Over time, the IMF has become less of an advocate of 'leaning against the wind', thus leaving macroprudential policies to play an even greater role in safeguarding financial stability. An IMF Policy Paper in 2015 took a fairly clear line:

In principle, monetary policy should deviate from its traditional response only if costs are smaller than benefits (the principle of doing no harm on net). Costs arise in the short term, from lower output and inflation. Benefits materialize mainly in the medium term, as financial risks are mitigated, though effects are more uncertain. Based on current knowledge, the case for leaning against the wind is limited, as in most circumstances costs outweigh benefits. 
Views seem to have evolved in similar fashion in many central banks and international institutions. Having elevated the importance of macroprudential policies, researchers at the IMF and elsewhere have devoted increased attention to studying the effectiveness of such policies in managing house price booms (IMF 2013, 2014). Cerutti et al. (2017) study the effects of several macroprudential policies for 119 countries over the 2000-13 period. They find that tightening these measures does significantly lower household credit growth; the impact on house price growth is also negative but not statistically significant. They argue that since "house price booms associated with increased leverage are the most destructive," macroprudential policies can play a useful role by "dampening household indebtedness." Over the same period but using a different data set of policy measures, Zhang and Zoli (2016) compare the impact in Asia, where the "economies appear to have made greater use of macroprudential tools, especially housing-related tools," with that in other regions. They find that housing-related policy measures have curbed real credit growth in Asia and other regions; in Asia these measures have lowered real house price growth as well but in other regions the impact on prices is not significant (Vandenbussche et al. 2015). ${ }^{2}$

In sum, while there is some evidence on effectiveness of macroprudential policies, it is mixed and it is difficult to be confident of medium-run effects given the short span of data that is available to researchers. Therefore, country-by-country assessments and detailed case studies of the use and effectiveness of macroprudential measures are useful.

\section{Time to Worry Again?}

As mentioned in the introduction, the IMF's Global House Price Index has inched back up to its pre-GFC level (Fig. 7.2). Does this reflect overvaluations in many countries, and if so, what policy actions are needed? The IMF has not provided recent updates of the overvaluation estimations reported in Fig. 7.1. ${ }^{3} \mathrm{We}$ make the case here, admittedly based on very casual empiricism, that there are a couple of important differences between the pre-GFC and post-GFC periods.

First, there is lower synchronization in house price growth across countries in the latter period than in the former; moreover, growth in quantities remains subdued. Second, countries are much more active in using macroprudential policies to manage house price booms- "the era of benign neglect of house price booms is over" (Zhu 2014) — and, as discussed in the previous section, there is some evidence that the policies are effective. On these two grounds, we argue that it is time for vigilance, not panic.

\footnotetext{
${ }^{2}$ Vandenbussche et al. (2015) find evidence of the effectiveness of some macroprudential policy measures on house price inflation in Central, Eastern, and South-Eastern Europe (2015).

${ }^{3}$ Some individual IMF country teams have provided estimates—see for example Geng (2018).
} 


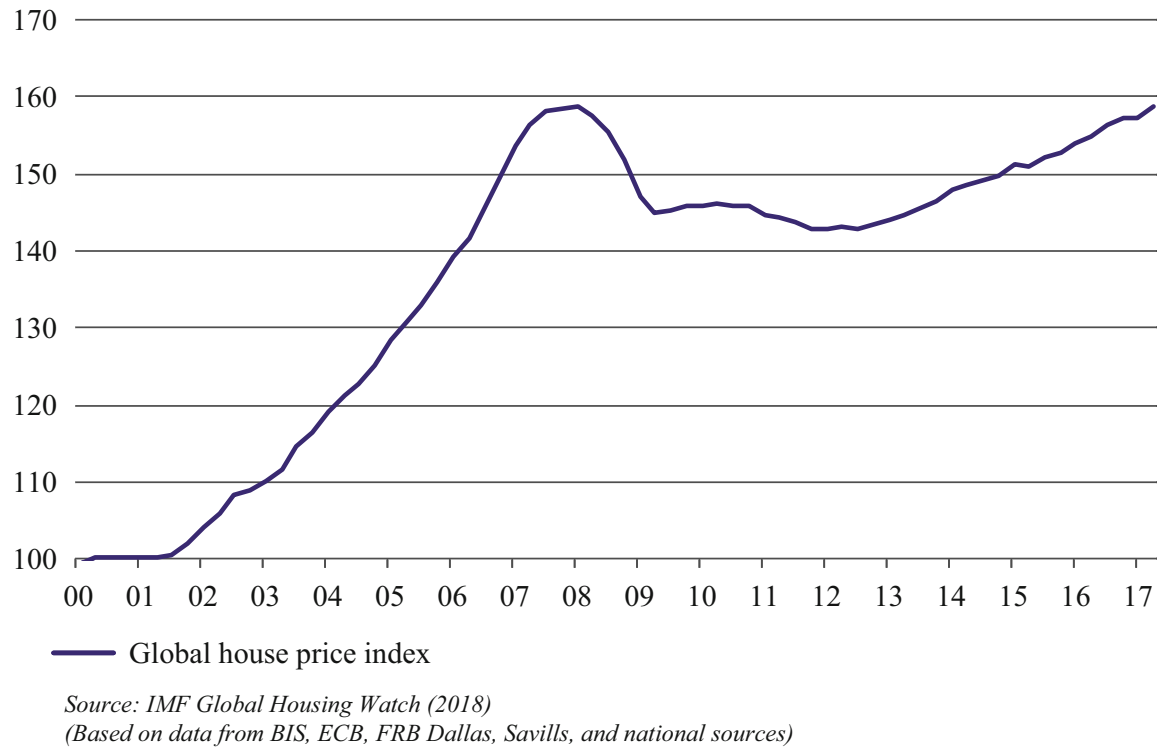

Fig. 7.2 Global house price index

To illustrate the differences in synchronicity, it is useful to segment the countries included in the global index into three clusters. The first cluster-gloom-consists of 14 economies in which house prices fell substantially at the onset of the Great Recession, and have remained on a downward path. ${ }^{4}$ The second cluster-bust and boom-consists of 19 economies in which housing prices fell sharp during 2007-12 but have since rebounded. ${ }^{5}$ The third cluster-boom-comprises 24 economies where the drop in house prices in 2007-12 was quite modest and followed by a quick rebound. ${ }^{6}$

Countries in the third cluster had a lower incidence of financial crisis and smaller output losses over the 2007-12 period (Fig. 7.3). House prices in these countries have, on average, resumed their pre-GFC trend rate of growth. In the second cluster, house prices are growing at a slower pace than before the crisis (Fig. 7.4). In contrast, the pre-GFC period was marked by synchronous behavior in house prices across all three groups. The behavior of residential permits - is also different across the two periods (Fig. 7.5). Pre-GFC, the 'bust and boom' cluster had a very rapid growth in permits; post-GFC the rate of increase for this group has been far more subdued.

\footnotetext{
${ }^{4}$ Brazil, Croatia, Cyprus, Finland, France, Greece, Italy, Macedonia, Morocco, Russia, Singapore, Slovenia, South Africa, and Ukraine.

${ }^{5}$ Bulgaria, Denmark, Estonia, Germany, Hungary, Iceland, Indonesia, Ireland, Japan, Latvia, Lithuania, Netherlands, New Zealand, Portugal, Serbia, Spain, Thailand, United Kingdom, and United States.

${ }^{6}$ Australia, Austria, Belgium, Canada, Chile, China, Colombia, Czech Republic, Hong Kong SAR, India, Israel, Kazakhstan, Korea, Malaysia, Malta, Mexico, Norway, Peru, Philippines, Poland, Slovak Republic, Sweden, Switzerland, and Taiwan POC.
} 


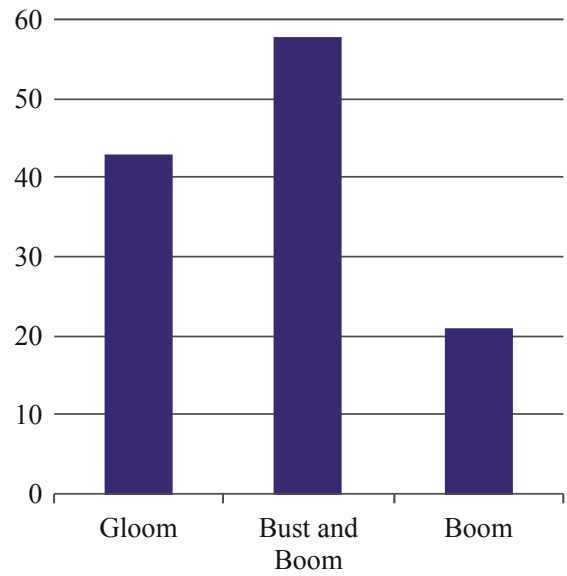

- Percent of countries experiencing a financial crisis: $2007-12$

Source: Based on data from "Systemic banking crises database: An update" by Valencia and Laeven (2012)

Fig. 7.3 Country clusters: incidence of financial crisis

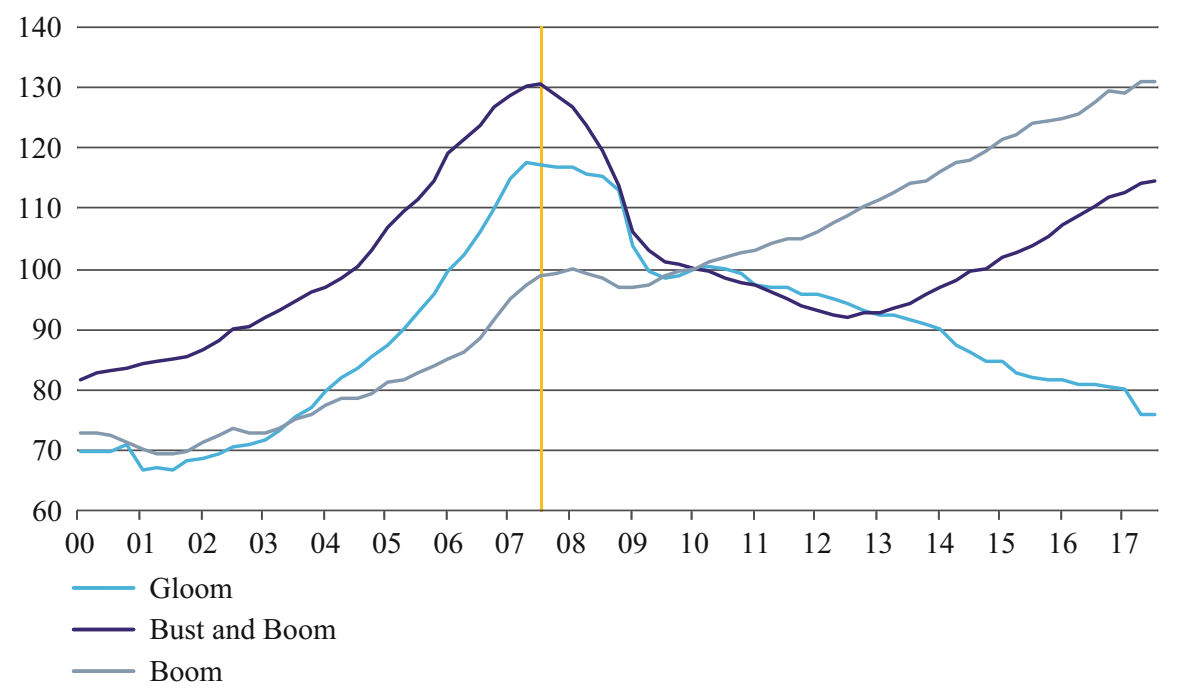

Source: IMF Global Housing Watch (2018)

Fig. 7.4 Country clusters: average house price indices

The extensive use of macroprudential policies to tame housing booms since the crisis is shown in Fig. 7.6. The main policies used are limits on loan-to-value (LTV) ratios, limits on debt-service-to-income (DSTI) ratios and sectoral capital requirements. 


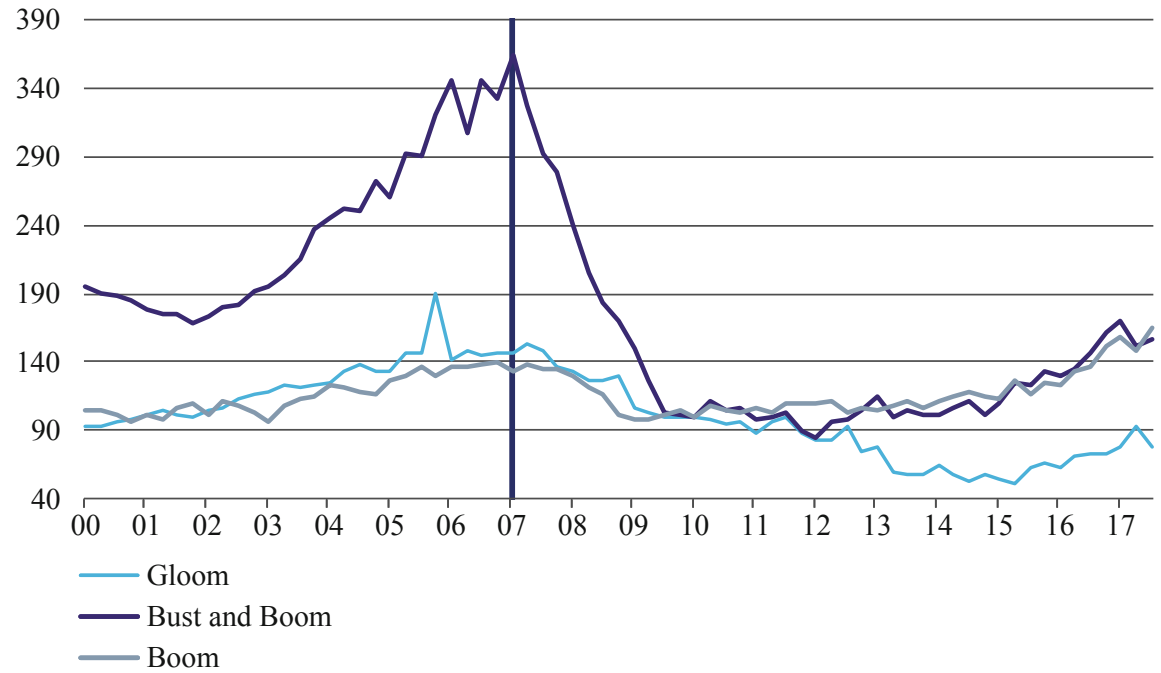

Source: Eurostat (2018), Haver Analytics, and OECD (2018)

Fig. 7.5 Housing permits in each cluster

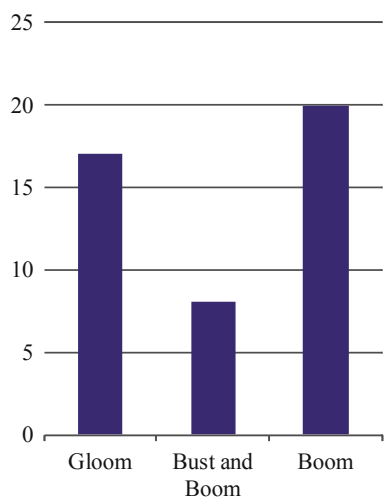

- Limits on loan-to-value ratios
25

20

15

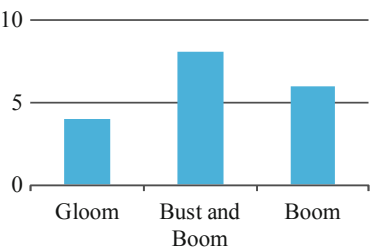

Caps on debt-service-to-income ratios

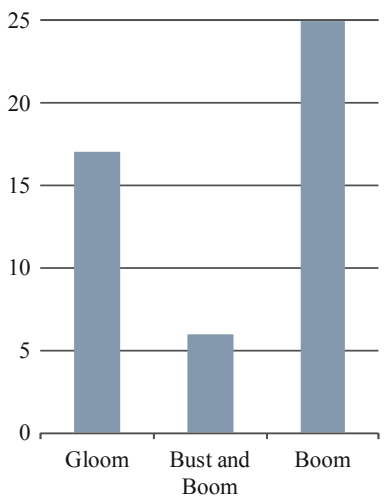

- Sectoral capital requirements

Source: International Monetary Fund (2018b)

Fig. 7.6 Use of macroprudential policies

\section{Dealing with Glocalization}

\subsection{Explaining Local Booms}

In recent years, there is some evidence that house prices in major cities are diverging from the national average and that booms are often restricted to one or a few cities. Some examples of local booms are Vienna, Vancouver, Amsterdam and London, where house prices are rising far more than the national average (Fig. 7.7). 

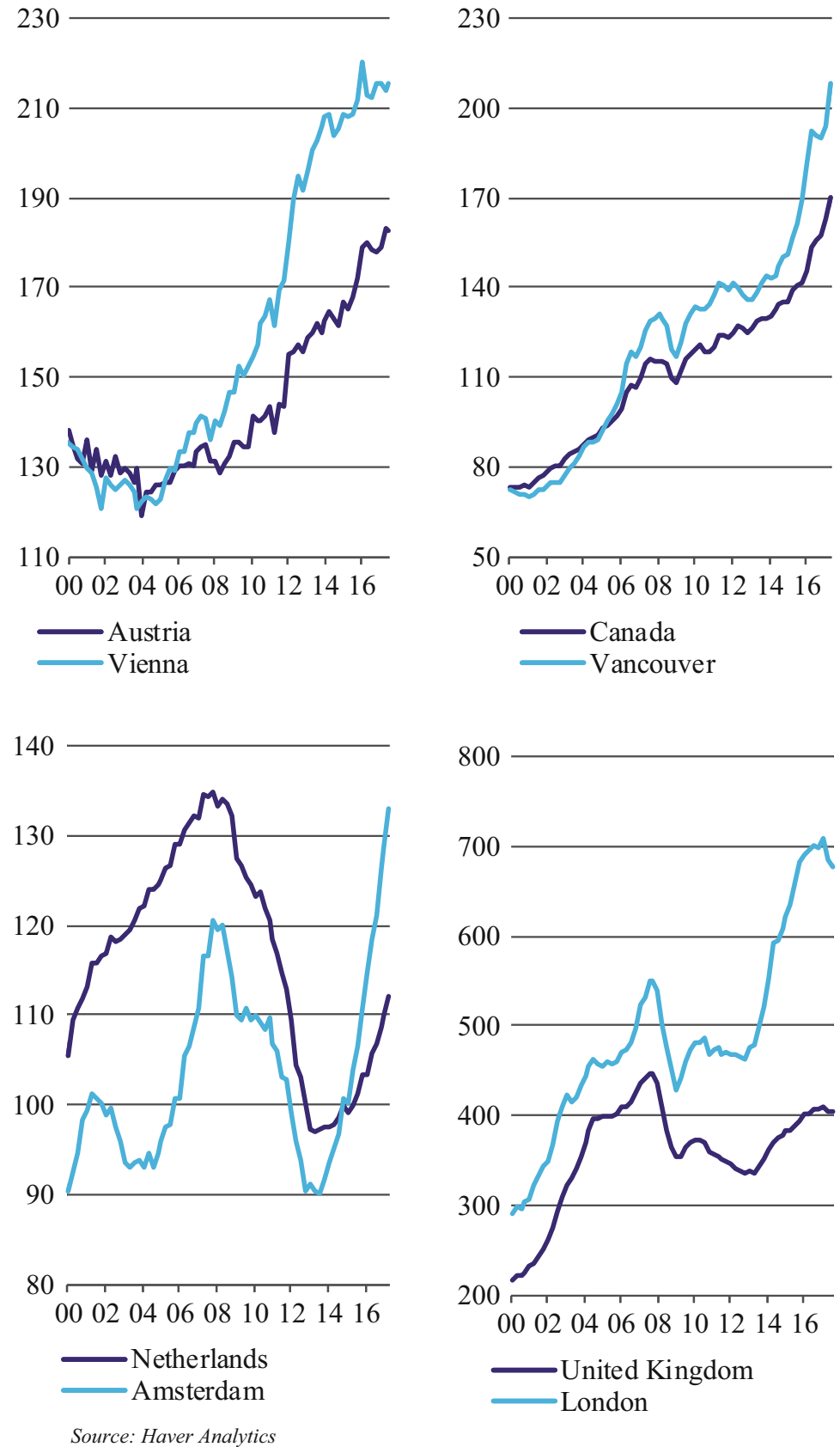

800

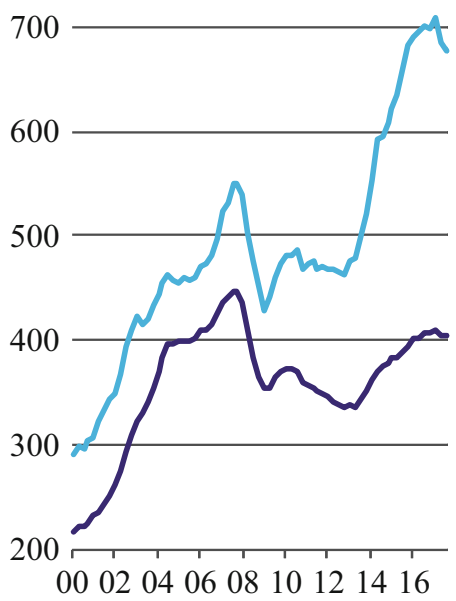

—United Kingdom London

Fig. 7.7 City-level booms 
In all these cases we again see a difference between the pre-GFC and post-GFC periods: prices in these cities moved much more in tandem with national prices in the former period.

Consequently, surveillance of housing markets by both national and international agencies is also turning to more granular data and seeking out explanations for the divergence between national-level and local developments. Along with other agencies, the IMF is being drawn into assessing whether there are house prices 'bubbles' in major cities. For example, in the case of Austria, the IMF's latest assessment was that there was an overvaluation of property prices of about $22 \%$ for Vienna, while prices in the rest of the country were broadly in line with fundamentals. In Japan, the IMF judged condominium prices appear to be moderately overvalued in Tokyo, Osaka, and several outer regions.

While assessments of housing price overvaluation at the national level are difficult, assessments of city-level overvaluation are likely even more so. Citylevel house prices reflect the confluence of local factors (supply constraints, regulations and zoning) and global trends (role of foreign investors; impact of migration; development of internet-based markets such as Airbnb) - the phenomenon of 'glocalization'.

The role of housing supply constraints in driving local house prices has been a staple in academic work. Glaeser et al. (2005) famously argued that it is "the interaction of strong latent demand for markets such as Manhattan combined with restrictive or inelastic supply that largely accounts for relatively high house prices in those places. Strong demand itself is not enough. Dallas has very strong demand, as population has grown substantially over many decades; yet, its constant quality house prices have not risen much at all in real terms. What is different about Dallas is plentiful building whenever prices rise enough for developers to supply new homes and make a normal profit. In Manhattan, local authorities are able to impose sufficiently high costs on new development (or simply limit it outright), so that higher demand results in higher prices without much increase in the number of housing units."

As it turns to more granular analysis of housing markets, the impact of supply constraints has been increasingly emphasized by the IMF in the case of many of cities with house price booms. In Copenhagen, the increase in the housing stock has not kept up with population growth, feeding some of the price increase that is observed there. Booms in Stockholm and Malmo have also been attributed in part to growth in the number of dwellings not keeping up with the population growth. In recent years, the IMF has also flagged the role of supply constraints in Australia and Canada, as well as in many European countries-France, Germany, Ireland, Netherlands, Norway and the United Kingdom.

Housing supply constraints have also been exacerbated by the global factors mentioned earlier-the growing role of international investors and internet-driven tourist booms. The IMF's April 2018a Global Financial Stability Report documents that institutional investors, private equity firms, and Real Estate Investment Trusts have been increasingly active in major cities such as Amsterdam, Sydney, and Vancouver as they seek out higher returns. In cities in Norway, the IMF flagged 
the impact of a large influx of asylum seekers. In Iceland, the IMF noted that the increase in housing prices of almost 10\% in 2016, centered on Reykjavík, appeared driven by the crowding out of homebuilding by hotel construction and of rentals by residents to tourists.

\subsection{Managing Local Booms}

In keeping with its advice to rely on macroprudential policies to manage housing booms, the IMF has been active in suggesting specific and targeted macroprudential policies to manage local booms. A few examples may suffice to give a flavor of the policy advice. In China, the IMF agreed that city-specific macroprudential policies were appropriate given the diversity in housing conditions, and should continue to be deployed to ensure a smooth adjustment in housing markets. In Macao, the IMF suggested that if the impact of speculative demand on real estate prices is a material concern, policymakers could consider more targeted macroprudential measures such as tighter loan-to-value ratios on second-home purchases. In Malaysia as well, the advice was that if rapid house price growth resumes, LTV caps on second and first mortgages could be considered.

However, along with local macroprudential policies, the IMF has also increasingly recommended policies to ease housing supply constraints. Again, a few examples may be illustrative of the nature of the policy advice. In Germany, the IMF suggested that encouragement for local authorities to relax zoning and height restrictions in areas under pressure and lowering the effective transaction tax rate on new construction. In Israel, the advice was to improve municipal incentives for development, ensure adequate land privatization and urban renewal, shorten approval times, and reduce construction costs.

\section{Concluding Remarks}

This chapter has traced the evolution in IMF surveillance of housing markets and its policy advice to countries on how to manage house price booms. Despite our focus on the IMF, the discussion should be of more general interest as other national and international agencies involved in monitoring and regulating housing markets have undergone a similar evolution. By now, there appears to be a broad consensus on the use of macroprudential policies to tame housing booms and some evidence that such policies are proving to be effective. However, the increasing shift in the action to the city-level raises a number of issues that will require increasing attention from policymakers.

First, several local and national authorities have taken measures to deter foreign real estate investors. The authorities view these as macroprudential measures needed for financial stability, whereas institutions like the IMF seem to consider some of 


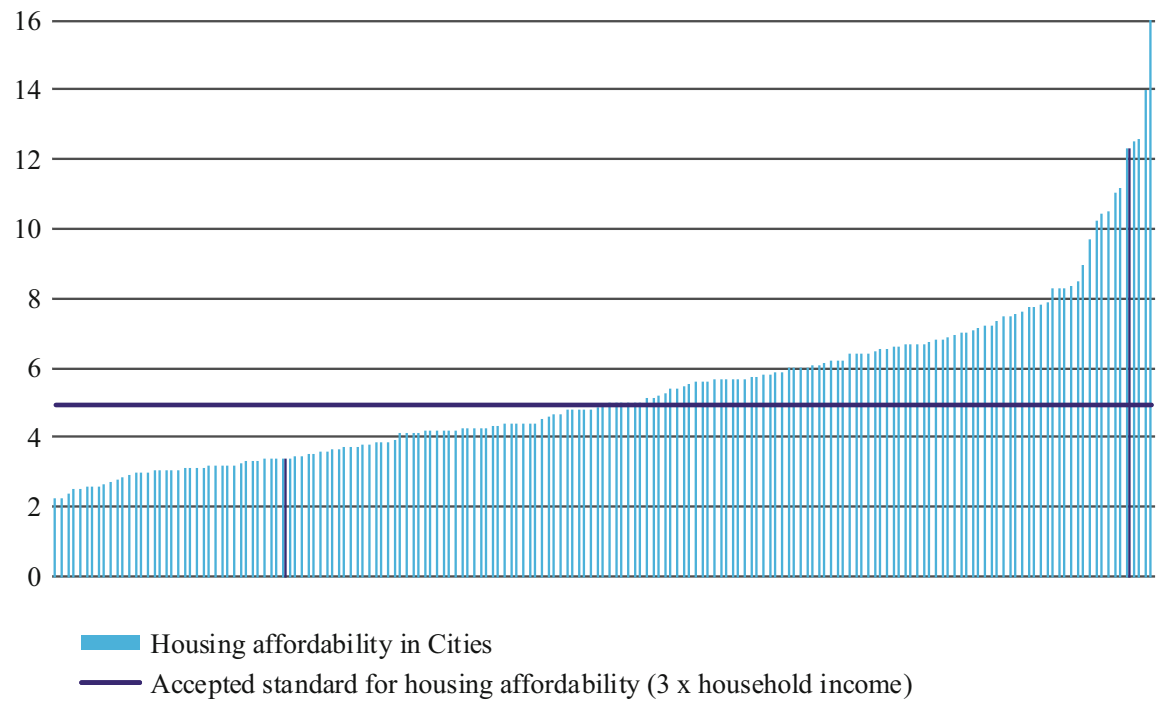

Source: Kallergis et al. (2018)

Fig. 7.8 Housing affordability in cities

them as capital flow management measures ('capital controls'). This is emerging as a point of contention.

Second, issues of housing affordability that often get lost when looking at national-level averages are much more salient at the city level. The UN's Land and Housing Survey of 170 cities shows that the median house-price-to-income ratio was 4.8 and the median rent-to-income ratio was $30 \%$ (Fig. 7.8), above what is considered affordable (house-price-to-annual household income ratio of 3.0, and rent-to-monthly household income ratio of under $25 \%$ ).

Third, the focus on city-level developments has also brought to the fore the need to view housing markets through a broader lens of growth and economic development. As argued by Ed Glaeser (2011), cities are essential for growth, which makes policy actions to manage city level housing booms much more than just a matter of financial stability. Affordability is becoming an issue in advanced countries, but the situation is worse in emerging markets and low-income countries, which are much more populous and where the need for sensible urban policies for development is much more pressing (Jedwab et al. 2018).

\section{References}

Cerutti, E., Claessens, S., \& Laeven, L. (2017). The use and effectiveness of macroprudential policies: New evidence. Journal of Financial Stability., 28, 203-224.

Eurostat. (2018). Building permits - quarterly data. Accessed July 1, 2018, from http://appsso. eurostat.ec.europa.eu/nui/show.do?dataset=sts_cobp_q\&lang=en 
Geng, N. (2018). Fundamental drivers of house prices in advanced economies (IMF Working Paper) (forthcoming).

Glaeser, E. (2011). Triumph of the city: How our greatest invention makes us richer, smarter, greener, healthier, and happier. New York: Penguin Books.

Glaeser, E. L., Gyourko, J., \& Saks, R. E. (2005). Why is Manhattan so expensive? Regulation and the rise in housing prices. The Journal of Law and Economics, 48, 331-369.

IMF, Global Housing Watch. (2018). Accessed July 1, 2018, from https://www.imf.org/external/ research/housing/

International Monetary Fund. (2008, April). World Economic Outlook.

International Monetary Fund. (2013, June). Key aspects of macroprudential policy (IMF Policy Paper).

International Monetary Fund. (2014, December). Staff guidance note on macroprudential policy (IMF Policy Paper).

International Monetary Fund. (2015, December). Monetary policy and financial stability (IMF Policy Paper).

International Monetary Fund. (2018a, April). Global financial stability report.

International Monetary Fund. (2018b). Macroprudential policy survey database. Accessed July 1, 2018, from https://www.elibrary-areaer.imf.org/Macroprudential/Pages/Home.aspx

Jedwab, R., Loungani, P., \& Yezer, T. (2018). New urban giants in low-income countries: Stylized facts about land areas, building heights, and interior density. Draft.

Kallergis, A., Angel, S., Liu, Y., Blei, A., Sanchez, N., \& Lamson-Hall, P. (2018, November). Housing affordability in a global perspective. Cambridge, MA: Lincoln Institute of Land Policy.

OECD. (2018). Permits issued for dwellings sa, Index. Accessed July 1, 2018, from https://stats. oecd.org/Index.aspx ?querytype $=$ view $\&$ queryname $=92$

Valencia, F., \& Laeven, L. (2012). Systemic banking crises database: An update. IMF Working Paper 12, no. 163: 1 .

Vandenbussche, J., Vogel, U., \& Detragiache, E. (2015). Macroprudential policies and housing prices: A new database and empirical evidence for Central, Eastern and Southeastern Europe. Journal of Money, Credit and Banking, 47(S1), 343-377.

Vinals, J. (2010, November 10). Towards a safer global financial system.

Zhang, L., \& Zoli, E. (2016). Leaning against the wind: Macroprudential policy in Asia. Journal of Asian Economics, 42, 33-52.

Zhu, M. (2014). Era of benign neglect of house price booms is over. IMFBlog. https://blogs.imf. org/2014/06/11/era-of-benign-neglect-of-house-price-booms-is-over/

Open Access This chapter is licensed under the terms of the Creative Commons Attribution 4.0 International License (http://creativecommons.org/licenses/by/4.0/), which permits use, sharing, adaptation, distribution and reproduction in any medium or format, as long as you give appropriate credit to the original author(s) and the source, provide a link to the Creative Commons licence and indicate if changes were made.

The images or other third party material in this chapter are included in the chapter's Creative Commons licence, unless indicated otherwise in a credit line to the material. If material is not included in the chapter's Creative Commons licence and your intended use is not permitted by statutory regulation or exceeds the permitted use, you will need to obtain permission directly from the copyright holder.

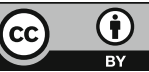

